\title{
Some Aspects of Reproductive Biology of Common Pandora (Pagellus Erthrinus) Collected from the Coast off Benghazi, Libya
}

\author{
Amina Elmajedeb, Houssein Elbaraasi*, Fatma Altomi and Hussein Jenjan \\ Faculty of Science, Department of Zoology, University of Benghazi, Libya
}

Submission: May 14, 2019; Published: May 30, 2019

Corresponding author: Houssein Elbaraasi, Faculty of Science, Department of Zoology, University of Benghazi, Libya

\begin{abstract}
The reproductive biology of Common Pandora (Pagellus erthrinus) collected from the coast off Benghazi, Libya were investigated. A total of 225 specimens were collected throughout a year of 2011-2012. The sex ratio was 0.22: 0.13: 0.65 for males to hermaphrodites to females. First maturation size for males were $(24.5 \mathrm{~cm})$, for hermaphrodite were $(25.0 \mathrm{~cm})$, and for females were $(22.0 \mathrm{~cm})$. In general, GSI in females group were higher than that found in males group. For the fecundity, the highest means values were recorded in April $(244344 \pm 104158)$ and in October (222794 \pm 73720 ). Nevertheless, the lowest fecundity values were recorded in February (4699 \pm 6356$)$ and in September (15504 \pm 20055).
\end{abstract}

Keywords: Common Pandora (Pagellus erthrinus), Reproductive, Benghazi, Libya.

\section{Introduction}

Understanding the reproductive biology of fish is the most important feature to provide a scientific suggestion for fisheries management and fish culture. Common Pandora Pagellus erythrinus is one of the most important commercial fish species in Libyan fishery production. It is an omnivorous species, but feed mostly as carnivorous. It is usually distributed in the Mediterranean Sea and along the European and African coasts of the Atlantic Ocean [1,2]. Moreover, P. erythrinus is a protogynous hermaphrodite, that is matures at first as a female and changes to a male after two years of age or wherever attaining a body length of $17-18 \mathrm{~cm}[3,4]$. Furthermore, it spawns from late spring to late summer on northern part of Mediterranean, at depths of $60-800 \mathrm{~m}$, wherever the temperature of water is approximately $16-21^{\circ} \mathrm{C}$ [5-7]. Consequently, the current study aimed to understanding some of the aspects of the reproductive biology of Pagellus erythrinus collected from coast off Benghazi, Libya.

\section{Material and Methods}

A total of 225 samples of Pagellus erythrinus (Mean total length $21.73 \pm 2.57 \mathrm{~cm}$ and mean body weight $138.75 \pm 54.30$ g) were monthly collected from December 2011 until November 2012 off the coast of Benghazi, Libya using gill nets with $40 \mathrm{~mm}$ stretched mesh size. The total body length and body weight were measured. Twenty scales were removed from different place of fish body to determine fish age. Fish was dissected and gonads were removed and weighted. The sex was determined by gonads morphology. The sex ratio (SR) was expressed as a percentage and determined according to Hossucu \& Cakir, [8] by the formula:

The Gonado-Somatic Index (GSI) were determined according to Micale \& Perdichizzi, [9] by the fallowing equation:

Fecundity was estimated for each maturing ovary by counting all ripening eggs. Eggs were separated and put in normal saline solution $(0.9 \% \mathrm{Na} \mathrm{Cl})$ for 24 hours and counted under light microscope at magnification of 40X. Fecundity was calculated according to Gaikwad et al. [10] by the fallowing equation: Fecundity $=\frac{(\text { Number of eggs in the sample } * \text { Ovary weight })}{\text { Weight of fish }}$

Oocytes were collected randomly from each ovary (left and right) and eggs diameter were measured using ocular micrometer using light microscope at $100 \mathrm{X}$.

\section{Results}

\section{Sex Ratio}

The overall sex ratio was 0.22: 0.13 : 0.65 for males to hermaphrodites to females (Table 1). Furthermore, the sex ratio of male to female was (1: 2.92) and male to hermaphrodites was (1: 0.58). The sex ratio was not regular during the different months and the number of males was smaller than the sex ratio 
of males in all months except in April. the sex ratio of males was larger than females. However, the sex ratio of hermaphrodite group was smaller than the sex ratio that in females' group, but larger than males' group in January, February, March and August.
In general, the maximum percentage of males was recorded in April (56 \%), but in females found in May (100\%) and in hermaphrodites the maximum percentage was in August (50 \%).

Table 1: Monthly variations in sex ratio of common pandora (Pagellus erythrinus) from December 2011 to November 2012 in Benghazi- Libya coast.

\begin{tabular}{|c|c|c|c|c|c|c|c|c|}
\hline Months & Fish No & Males No & Males \% & $\begin{array}{c}\text { Hermaphrodite } \\
\text { No }\end{array}$ & $\begin{array}{c}\text { Hermaphrodite } \\
\text { \% }\end{array}$ & Females No & $\begin{array}{c}\text { Females } \\
\text { \% }\end{array}$ & $\begin{array}{c}\text { Sex ratio (Male\%: } \\
\text { Hermaphrodite\%: } \\
\text { Female\%) }\end{array}$ \\
\hline Dec. (2011) & 16 & 6 & 38 & 0 & 0 & 10 & 63 & $0.38: 0.00: 0.63$ \\
\hline $\begin{array}{c}\text { January } \\
(2012)\end{array}$ & 16 & 0 & 0 & 5 & 31 & 11 & 69 & $0.00: 0.31: 0.69$ \\
\hline Feb. & 20 & 3 & 15 & 4 & 20 & 12 & 60 & $0.15: 0.20: 0.60$ \\
\hline Mar. & 18 & 0 & 0 & 3 & 17 & 13 & 72 & $0.00: 0.17: 0.72$ \\
\hline Apr. & 16 & 9 & 56 & 0 & 0 & 7 & 44 & $0.56: 0.00: 0.44$ \\
\hline May. & 18 & 0 & 0 & 0 & 0 & 18 & 100 & $0.00: 0.00: 1.00$ \\
\hline Jun. & 20 & 8 & 40 & 0 & 0 & 12 & 60 & $0.40: 0.00: 0.60$ \\
\hline Jul. & 17 & 4 & 24 & 3 & 18 & 9 & 53 & $0.42: 0.18: 0.53$ \\
\hline Aug. & 16 & 2 & 13 & 8 & 50 & 9 & 56 & $0.13: 0.50: 0.56$ \\
\hline Sep. & 30 & 14 & 47 & 3 & 10 & 14 & 47 & $0.14: 0.10: 0.47$ \\
\hline Oct & 18 & 3 & 17 & 2 & 11 & 13 & 72 & $0.17: 0.11: 0.72$ \\
\hline Nov. & 20 & 1 & 5 & 1 & 5 & 18 & 90 & $0.50: 0.50: 0.90$ \\
\hline Total & 225 & 50 & 22 & 29 & 13 & 146 & 65 & $0.22: 0.13: 0.65$ \\
\hline
\end{tabular}

Table 2: Length at first sexual maturity for male, hermaphrodites and females of Pagellus erythrinus collected from Benghazi-Libya coast.

\begin{tabular}{|c|c|c|c|}
\hline \multirow{2}{*}{ Sex } & \multicolumn{3}{|c|}{ Total body length groups (cm) } \\
\hline & $18-22.9$ & $23-27.9$ & $28-32.9$ \\
\hline Males (\%) & 13.3 & 8.4 & 0.4 \\
\hline Hermaphrodites (\%) & 9.8 & 2.7 & 1.3 \\
\hline Females (\%) & 52 & 10.7 & 2.2 \\
\hline Total (\%) & 75.1 & 21.8 & 3.9 \\
\hline
\end{tabular}

\section{Length at the first Sexual Maturity}

The percentage of sexes at different total body length for males, hermaphrodites and females showed in Table 2. First maturation size for males were $(24.5 \mathrm{~cm})$, for hermaphrodite were $(25.0 \mathrm{~cm})$, and for females were $(22.0 \mathrm{~cm})$ (Table 2).

Table 3: Percentages for males, hermaphrodites and females at different ages.

\begin{tabular}{|c|c|c|c|c|c|c|c|}
\hline \multirow{2}{*}{ Sex } & \multicolumn{7}{|c|}{ Age (year) } \\
\cline { 2 - 8 } & $\mathbf{1}$ & $\mathbf{2}$ & $\mathbf{3}$ & $\mathbf{4}$ & $\mathbf{5}$ & $\mathbf{6}$ & $\mathbf{7}$ \\
\hline Males (\%) & 0.4 & 6.2 & 10.6 & 3.5 & 0.8 & 0.4 & 0 \\
\hline Hermaphrodites (\%) & 0.4 & 5.3 & 4.8 & 0.8 & 0.4 & 0.4 & 0.4 \\
\hline Females \% & 1.6 & 33.3 & 14.6 & 3.11 & 2.2 & 0.8 & 0 \\
\hline Total \% & 11.4 & 44.8 & 30 & 7.4 & 3.4 & 1.6 & 0.4 \\
\hline
\end{tabular}

\section{Sex at Different Ages}

The percentages for males, hermaphrodites and females at different ages are showed in Table 3. For all groups the percentages at different ages were $11.4 \%$ at $1^{\text {st }}$ year, $44.8 \%$ at $2^{\text {nd }}$ year, $30.0 \%$ at $3^{\text {rd }}$ year, $7.4 \%$ at $4^{\text {th }}$ year, $3.4 \%$ at $5^{\text {th }}$ year, $1.6 \%$ at $6^{\text {th }}$ year and $0.4 \%$ at $7^{\text {th }}$ year. Furthermore, females' group were youngest in mean age (Table 3 ).

\section{Gonado-Somatic Index (GSI)}

The monthly variation of the GSI are shown in Figures $1 \& 2$. For all groups (males and females) of P. erytherinus, the highest mean values of GSI observed in April, however, the lowest mean values have been found in August. In general, GSI in females' group were higher than that found in males' group. In males, GSI increased in April (1.39 \pm 0.30$)$ and June (1.16 \pm 0.45$)$ 
afterward started to decrease in July $(0.56 \pm 0.12)$ to September $(0.48 \pm 0.30)$ but returned to increase in October $(1.38 \pm 0.70)$. Although, in females' group, GSI start increasing from February $(1.12 \pm 0.51)$ to July $(2.45 \pm 0.15)$ but decline in August $(0.43$ $\pm 0.20)$ and returned to increase in October $(2.41 \pm 1.32)$, then decreased in November $(1.04 \pm 0.43)$.

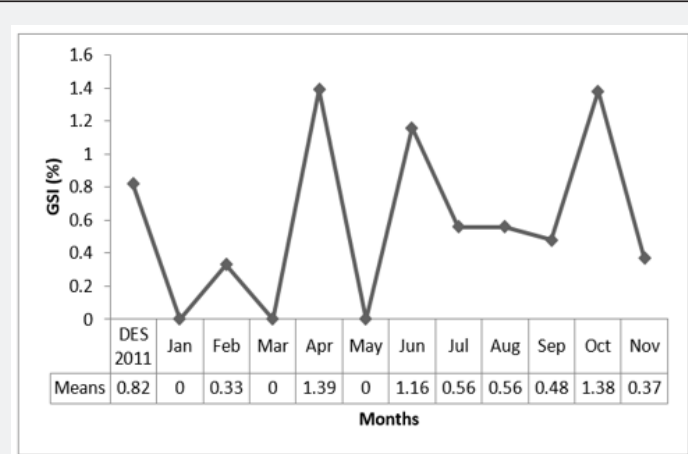

Figure 1: Variations of monthly in the means of SGI of Pagellus erythrinus males collected from coast of Benghazi-Libya.

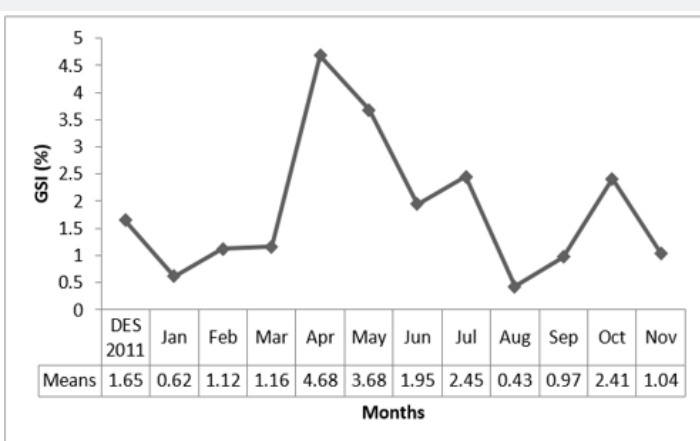

Figure 2: Variations of monthly in the means of SGI of Pagellus erythrinus females collected from coast of Benghazi-Libya.

\section{Fecundity and Eggs Diameters}

Table 4: Monthly variation of means $( \pm S D)$ in Fecundity and eggs diameters of Pagellus erythrinus in coast of Benghazi-Libyan.

\begin{tabular}{|c|c|c|}
\hline Months & $\begin{array}{c}\text { Fecundity (Mean } \\
\mathbf{\mathbf { S D } \text { ) }}\end{array}$ & $\begin{array}{c}\text { Eggs diameters } \\
\text { (Means } \pm \text { SD) }\end{array}$ \\
\hline Dec. (2011) & \pm & $109 \pm 51$ \\
\hline January (2012) & \pm & $120 \pm 30$ \\
\hline Feb. & $4699 \pm 6356$ & $131 \pm 19$ \\
\hline Mar. & $46578 \pm 37462$ & $147 \pm 15$ \\
\hline Apr. & $244344 \pm 104158$ & $444 \pm 16$ \\
\hline May. & $148203 \pm 11743$ & $489 \pm 48$ \\
\hline Jun. & $101388 \pm 38706$ & $552 \pm 97$ \\
\hline Jul. & $156427 \pm 73218$ & $610 \pm 102$ \\
\hline Aug. & \pm & $90 \pm 14$ \\
\hline Sep. & $15504 \pm 20055$ & $109 \pm 23$ \\
\hline Oct & $222794 \pm 73720$ & $297 \pm 46$ \\
\hline Nov. & $88642 \pm 18961$ & $184 \pm 109$ \\
\hline
\end{tabular}

* $=$ The fecundity was difficult to measure.
Monthly variation of means $( \pm$ SD) for fecundity and eggs diameter of Pagellus erythrinus showed in Table 4. For the fecundity, the highest means values were recorded in April (244344 \pm 104158$)$ and in October (222794 \pm 73720$)$. Nevertheless, the lowest fecundity values were recorded in February (4699 \pm 6356) and in September (15504 \pm 20055$)$. Furthermore, significantly differences $(p<0.05)$ were found between months, except between April and October and between May and July were no significantly differences ( $p>0.05)$. For the egg's diameters, the highest mean values were found in July (610 $\mu \mathrm{m} \pm 102$ ). However, the lowest mean value was found in August $(90 \mu \mathrm{m} \pm 14)$ (Table 4).

\section{Discussion}

The common pandora is a demersal fish belonging to the Actinopterygii, sparidae family. This fish is extensively distributed in continental shelf of the Mediterranean Sea. Therefore, the aims of this present study were to investigate some features of the reproductive biology of common pandora Pagellus erythrinus collected from Benghazi, Libya coast. The common pandora is a protogynous hermaphrodite, that is matures first as female and changes to male after two years of age or when attaining a body length of $17-18 \mathrm{~cm}$ [11]. The sex ratio is an important parameter for understanding reproductive pattern and fish culture [4]. In the current study the sex ratio of males to females of common pandora was 1:2.92, and these results are like results of common pandora in Al-Khoma, Libyan coast. Hossucu \& Cakir, [8] resulted that, the sex ratio of common pandaora females to males was 1:3.16. The sex ratio is not regular thought the diverse months, mainly through the reproduction season of each fish species [12]. The sex ratio of males to females was low, this could connect to protogynous hermaphroditism. Furthermore, the females are heavy and obtain caught in the gear in great number, consequential in an unhinged sex ratio. In the current study, the size of maturation for males were $22.34 \mathrm{~cm}$ and for females were $21.36 \mathrm{~cm}$. These results are like results have recorded by Pajuelo \& Lorenzo, [5] and Sweelem, [13]. This result indicated that, males of common pandora longer than females. These could be related to sex changes from male to female and temperature of water $[7,4]$.

In the current study, the GSI values of females were higher than those of males, and this like study by Hossucu and Cakir (8) and Mtin et al., [4] in the same species from different body water and geographical location. The highest values of GSI were during spring for whole samples, but reproductive season of common pandora happening mostly in the late spring and early summer with a peak in spawning activity in April and May in Coast of Benghazi. This result confirmed with results of Valdes [14] and results of Sweelem [13] on common pandora. The spawning period of common pandora is differ in deferent study area. For examples, the reproductive season of common pandora in Canary Island extended from April to September, with a peak in spawning activity in June and July, and in Portugal extends 
from March to July, with a peak during May to June. The present study showed that the highest fecundity was through spawning season (from April to July and October). Also, eggs diameters were gradually increased toward spawning season. This result confirmed with results of Yueh \& Chang [15] on black porgy (Acanthopagrus schlegeli). The raise in diameters of egg could be related to the deposition of large quantity of proteins and lipids that arrives from food and water temperature through the developing eggs $[1,12]$.

\section{References}

1. Klimogianni A, Koumoundouros G, Kaspiris P and Kentouri M (2004) Effect of temperature on the egg and yolk-sac larval development of common pandora Pagellus erythrinus. Marine Biology 145(5): 10151022.

2. Froese R and Pauly D (2010) Fish Base.

3. Klaoudatos SD, Lakovopoulos G and klaoudatos DS (2004) Pagellus erythrinus (common pandora): a promising candidate species for enlarging the diversity of aquaculture production. Aquaculture International 12(3): 299-320.

4. Mentin G, Llkaz AT, Soykan O and Kinacigil HT (2011) Biological characteristics of the common pandora, Pagellus erythrinus (Linnaeus, 1758), in the central Aegean Sea. Turkish Journal of Zooology 35(3): 307-315.

5. Pajuelo G and Lorenzo M (1998) Population biology of the common pandora Pagellus erythrinus (Pisces: Sparidae) of the Canary Islands. Fisheries Research 36(2-3): 75-86.

6. Somarakis S and Machias A (2002) Age, growth and bathymetric distribution of red pandora on the Cretan shelf (eastern Mediterranean). Journal of Marine Biology Association of UK 82(1): 149-160.
7. Coelho R, Bentes L, Correia C, Goncalves JMS, Lino PG, et al. (2010) Life history of the common pandora, Pagellus erythrinus (L, 1758) (actinopterygii: sparidae) from southern Portugal. Brazilian Journal of Oceanography 58(3): 233-245.

8. Hossucu B and Cakir DT (2003) Some parameters about population biology of the common pandora (Pagellus erythrinus, L, 1758) (Sparidae) in the Edremit Bay (Turkey). Journal of Fisheries and Aquatic Sciences 20(3-4): 329-336.

9. Micale V and Perdichizzi F (1990) Gonadal responsiveness to photoperiod extension in captivity born Sparus aurata (L.) during the male phase. Bolletino di Zoologia 57(1): 21-26.

10. Gaikwad MV, More VR, Shingare SM, Hiwarale DK and Khillare YK (2009) Study on Gonado-Somatic and Fecundity relationship in air breathing fish Ghanna gachua (Ham) from Godavari near Aurangabad. African Journal of Basic and Applide Sciences 1(5-6): 93-95.

11. Klaoudatos SD and klaoudatos DS (2004) Brood stok formation of the hermaphrodite finfish species Pagellus erythrinus (common pandora) from fish reared in captivity. Mediterranean Marine Science 5 (1): 5-17.

12. El-Mor M, Moftah SAM, Abdalafid YKA and Abdulnabi BM (2016) Some aspects of reproductive physiology of the Flathead grey mullet Mugil cephalus (Linnaeus, 1758) in Benghazi coast, eastern Libya. International Journal of Bioassays 5(4): 4996-4999.

13. Swelem MA (2010) Biological study on common pandora (Pagellus erythrinus) at Al-Khoms coast, Libya. Faculty of Science, El-Marghib University.

14. Valdes P, Garcia-Alcazar A, Abdel I, Arizcan M, Suarez C (2004) Seasonal changes on gonadosomatic index and maturation stages in common pandora Pagellus erythrinus (L.). Aquaculture International 12(4-5): 333-343.

15. Yueh W and Chang C (2000) Morphological changes and competence of maturing Oocytes in the Portandrous Black Porgy, Acanthopagrus schlegeli. Zoological Studies 39(2): 114-122.

\section{Your next submission with Juniper Publishers will reach you the below assets}

- Quality Editorial service

- Swift Peer Review

- Reprints availability

- E-prints Service

- Manuscript Podcast for convenient understanding

- Global attainment for your research

- Manuscript accessibility in different formats

( Pdf, E-pub, Full Text, Audio)

- Unceasing customer service

Track the below URL for one-step submission

https://juniperpublishers.com/online-submission.php 